\title{
COLORS FOR POLYSTYRENE PLASTICS
}

\section{COMMERCIAL STANDARD CS156-49}

Effective Date For New Production From January 1, 1949

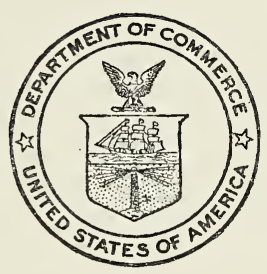

\section{A RECORDED VOLUNTARY STANDÁRD}

OF THE TRADE

UNITED STATES DEPARTMENT OF COMMERCE

CHARLES SAWYER, Secrotary

For sale by the Superintendent of Documents, U. S. Government Printing Office Washington 25, D. C. - Price 5 cents 


\section{COMMODITY STANDARDS}

Simplified Practice Recommendations and Commercial Standards are developed by manufacturers, distributors, and users in cooperation with the Commodity Standards Division of the National Bureau of Standards. The purpose of Simplified Practice Recommendations is to eliminate avoidable waste through the establishment of standards of practice for stock sizes and varieties of specific commodities that currently are in general production and demand. The purpose of Commercial Standards is to establish standard methods of test, rating, certification, and labeling of commodities, and to provide uniform bases for fair competition.

The adoption and use of a Simplified Practice Recommendation or Commercial Standard is voluntary. However, when reference to a Commercial Standard is made in contracts, labels, invoices, or advertising literature, the provisions of the standard are enforceable through usual legal channels as a part of the sales contract.

A Simplified Practice Recommendation or Commercial Standard originates with the proponent industry. The sponsors may be manufacturers, distributors, or users of the specific product. One of these three elements of industry submits to the Commodity Standards Division the necessary data to be used as the basis for developing a standard of practice. The Division, by means of assembled conferences or letter referenda, or both, assists the sponsor group in arriving at a tentative standard of practice and thereafter refers it to the other elements of the same industry for approval or for constructive criticism that will be helpful in making any necessary adjustments. The regular procedure of the Division assures continuous servicing of each effective Simplified Practice Recommendation and Commercial Standard, through review and revision, whenever, in the opinion of the industry, changing conditions warrant such action. Simplified Practice Recommendations and Commercial Standards are printed and made available by the Department of Commerce through the Government Printing Office.

\section{COMMERCIAL STANDARD FOR COLORS FOR POLYSTYRENE PLASTICS}

On September 20, 1948, a Recommended Commercial Standard for Colors for Polystyrene Plastics, adjusted in accordance with comment from interested organizations, was circulated to the trade for written acceptance. Those concerned have since accepted and approved the standard as shown herein.

Project Manager: F. W. REynolds, Commodity Standards Division, National Bureau of Standards; assisted by $\mathrm{H}$. A. BONNET, Commodity Standards Division, National Bureau of Standards.

Technical Advisers: Dr. D. B. JudD, HARry J. KeEGAN, and K. L.

KELLY, Electricity and Optics Division, National Bureau of Standards. 


\section{COMMERCIAL STANDARD CS156-49}

\section{for \\ COLORS FOR POLYSTYRENE PLASTICS}

\section{PURPOSE}

1.1. The purpose of this commercial standard is to promote understanding, and to facilitate the sale and purchase of colored polystyrene plastic materials and products. Among the results to be accomplished are:

1.1.1. Clear understanding between molders, manufacturers, and purchasers of goods as to the exact color wanted; an easy method of designating colors, allowing simpler contracts with purchasers of molded products, with less chance of error.

1.1.2. Fewer rejections of material and finished goods.

1.1.3. Quicker deliveries because colors can be stocked; smaller inventories for molders; simpler storage and stocking of colored products; faster turnover of material and finished goods.

1.1.4. Interchangeability of finished products; less hazard of obsolescence of consumers' goods in hands of molders and their customers.

1.2. The adoption of standard colors is not intended to restrict the production of other colors. It is the intent that plastic materials manufacturers will continue their custom of the past in supplying any colors desired by their customers when the amount involved warrants it, such colors being furnished without reference to this commercial standard.

\section{SCOPE}

2.1. This standard covers five transparent colors and thirteen translucent colors adopted as standard by the industry. It defines the standard colors in reproducible terms; specifies tolerances; provides for standard samples and designations to be used by materials manufacturers, molders, and purchasers in specifying the colors desired.

\section{REQUIREMENTS}

3.1. Colors.-The 18 colors covered by this commercial standard are specified in tables 1 and 2 . 
TABLE 1.-Transparent plastics

\begin{tabular}{|c|c|c|c|}
\hline \multirow{2}{*}{$\begin{array}{c}\text { Color designa- } \\
\text { tion }\end{array}$} & \multicolumn{2}{|c|}{$\begin{array}{l}\text { Chromaticity } \\
\text { coordinates }\end{array}$} & \multirow{2}{*}{$\begin{array}{c}\text { Daylight } \\
\text { trans- } \\
\text { mittance, } \\
Y(\%)\end{array}$} \\
\hline & $x$ & $y$ & \\
\hline Clear: & & & \\
\hline PSP -100 & 0.312 & 0.318 & 88.7 \\
\hline $\begin{array}{l}\text { Green: } \\
\text { PSP-117 }\end{array}$ & 283 & 370 & 564 \\
\hline Blue: & & & \\
\hline PSP-146 & .157 & .107 & 11.3 \\
\hline PSP-157 & .512 & .483 & 61.4 \\
\hline $\begin{array}{l}\text { Red: } \\
\text { PSP-172 }\end{array}$ & .691 & .309 & 9.5 \\
\hline
\end{tabular}

1 See footnote 3 of table 2.

3.2. Tolerances.-Articles supplied as conforming to the colors of this standard shall conform to the designated standard sample, under daylight and under incandescent lamp illumination, within 5 NBS units ${ }^{1}$ of color difference, except color PSP-34, which shall conform within 3 NBS units; and colors PSP-00 and PSP-01, which shall conform within 2 NBS units.

3.3. Standard samples. - Standard samples shall be made of polystyrene plastic material, and will be available from the Plastic Materials Manufacturers Association, Tower Building, 14th and K Streets, Northwest, Washington 5, D. C., for $\$ 3.00$ per set of 18 . Standard samples shall conform to the ICI specifications given in tables 1 and 2 (i. e., shall be duplicates of the originally adopted samples) within a tolerance of 1 NBS unit.

\section{IDENTIFICATION}

4.1. It is recommended that plastic materials and products conforming to colors covered by this commercial standard be identified by means of labels, tags, invoices, etc. The following statement is recommended:

The color of this polystyrene plastic article (or polystyrene plastic molding material) conforms to color PSP- , as specified in Commercial Standard CS156-49, developed by the trade under the procedure of the National Bureau of Standards, and issued by the U. S. Department of Commerce.

4.2 When available space on labels is insufficient for the full statement in legible type, an abbreviated statement as follows is recommended:

Complies with CS156-49, as developed by the trade, and issued by the U. S. Department of Commerce.

See Appendix, page 5 . 


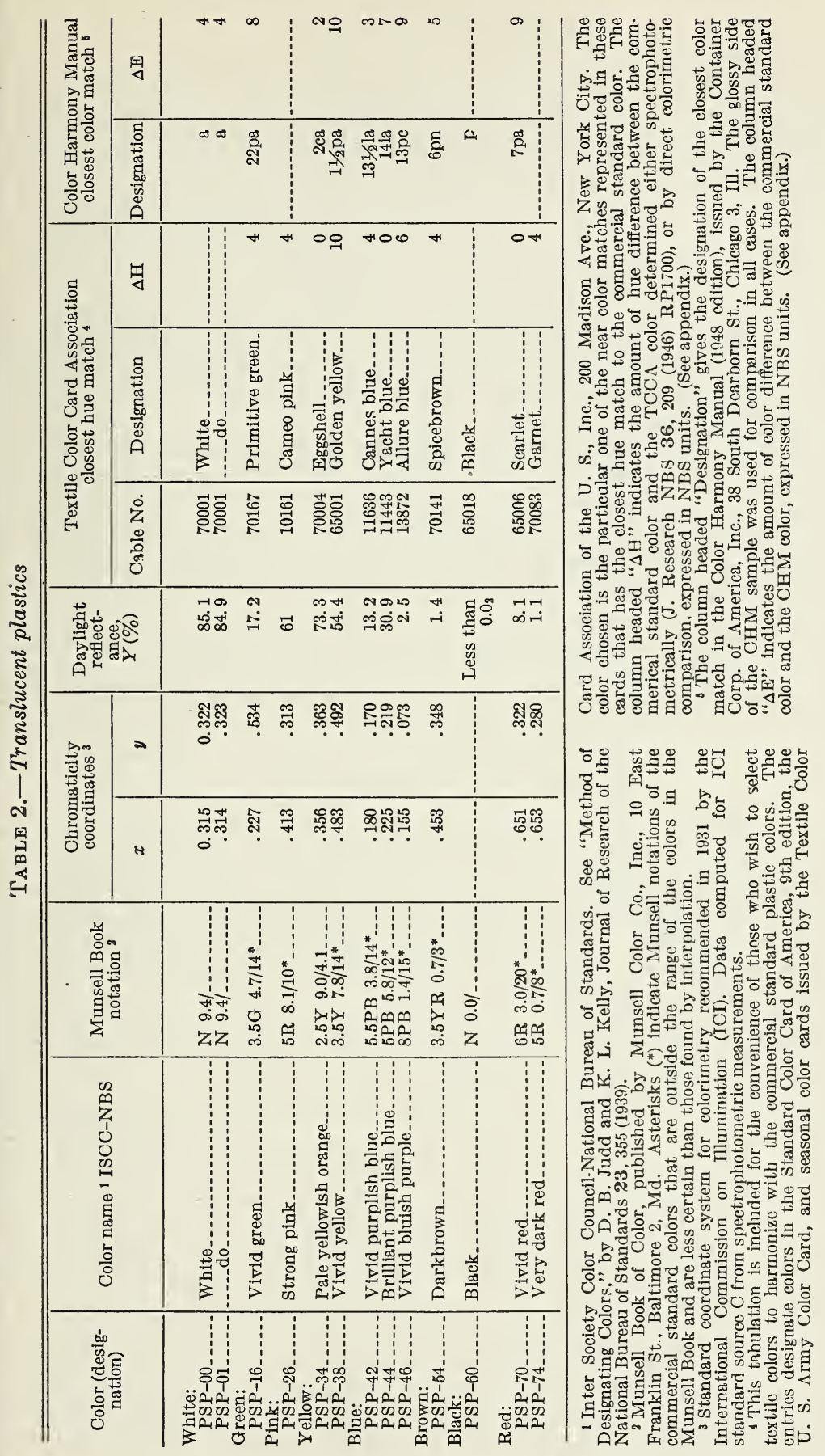




\section{EFFECTIVE DATE}

5. Having been passed through the regular procedure of the Commodity Standards Division, and approved by the acceptors hereinafter listed, this commercial standard was issued by the United States Department of Commerce, effective from January 1, 1949.

Edwin W. Ely,

Chief, Commodity Standards Division.

\section{HISTORY OF PROJECT}

6. On October 18, 1946, the Plastic Materials Manufacturers Association requested the cooperation of the National Bureau of Standards in the establishment of a commercial standard for colors for polystyrene plastics.

After circularization of the industry to ascertain extent of interest in the project, a set of 18 tentative molded color samples was mailed on October 9, 1947, to all interested parties, and comment was requested on the selection of colors. Following receipt of comment on the selection of colors, appropriate adjustments were made, and a Recommended Commercial Standard was circulated to the trade on September 20, 1948.

On December 27, 1948, having received acceptances in writing estimated to represent a satisfactory majority, announcement was issued that the commercial standard, designated CS156-49, would become effective for new production on January 1, 1949.

\section{STANDING COMMITTEE}

7. The following individuals comprise the membership of the standing committee, which is to review, prior to circulation for acceptance, revisions proposed to keep the standard abreast of progress. Comment concerning the standard and suggestions for revision may be addressed to any member of the committee or to the Commodity Standards Division, National Bureau of Standards, which acts as secretary for the committee.

F. H. Carman (Chairman), Plastic Materials Manufacturers Association, Inc., 731 Tower Building, Washington 5, D. C.

C. F. Cummins, Dow Chemical Company, Midland, Mich.

J. R. TURnbuli, Plastics Division, Monsanto Chemical Company, Springfield 2, Mass.

T. C. Keeling, Jr., Chemical Division, Koppers Company, Inc., Pittsburgh 19, Pa.

W. C. A ustrin, Bakelite Corporation, 30 E. 42d Street, New York 17, N. Y.

Mrs. Margaret H. Rorke, The Textile Color Card Association of the United States, Inc., 200 Madison Avenue, New York 16, N. Y.

Walter C. Granville, Container Corporation of America, 38 South Dearborn Street, Chicago 3, Ill.

Horace Gooce, Worcester Moulded Plastics Co., 14 Hygeia Street, Worcester 8, Mass.

Jules P. GrTs, Gits Molding Corporation, 4600 West Huron Street, Chicago 44, Ill.

Carl J. Luster, Lincoln Plastics Corporation, 14th Street and Burgess Avenue, Cambridge, Ohio.

Alfred C. Manovill, Ideal Plastics Corporation, 184-10 Jamaica Avenue, Hollis 7, Long Island, N. Y. 


\title{
APPENDIX
}

\section{THE NBS UNIT OF COLOR DIFFERENCE}

\author{
By D. B. Judd
}

The size of any color difference may be found in NBS units by calculation from the ICI tristimulus values $(X, Y, Z)$ of the two colors, and it may also be found from colorimetric comparison of the two specimens. If the specimens are of similar composition and essentially nonfluorescent, the determination may be made by means of a photoelectric tristimulus colorimeter as described in NBS Circular C429.

The size of the difference may also be estimated conveniently and with considerable reliability from the Munsell renotations of the two colors. One NBS unit corresponds approximately to 0.10 Munsell value step, to 0.15 Munsell chroma step and to 0.25 Munsell hue step at chroma 10, or to 2.5 Munsell hue steps at chroma 1 . If the two colors differ in more than one dimension the number of NBS units may be estimated by taking the sum of the NBS units in each dimension.

The NBS unit of color difference is intended to be so small that color differences of less than one unit will be perceptually unimportant in most commercial transactions. This unit is about 3 or 4 times the smallest color difference perceptible with certainty under the best conditions of observation by a trained inspector. One NBS unit is regarded as a reasonable tolerance within which a working standard of color should duplicate the master standard. This applies to incandescent-lamp light as well as daylight illumination.

In specifying $5 \mathrm{NBS}$ units as a tolerance within which the colors of products shall conform to the working standard, the desire was to avoid a strict tolerance that would work undue hardship on the manufacturer, or cause unwarranted cost to the purchaser. A difference of 5 NBS units is quite easily detected by an inspector under favorable conditions of observation (i. e., uniform illumination, large areas for comparison and proximity of compared areas, similarity of shape and surface texture, and absence of specular reflections or reflections from colored surroundings); indeed, a difference of double that amount is likely to give the impression that the two colors are distinctly different rather than one being merely a variation or shade of the other. On the other hand, the complex shapes of most articles manufactured from plastic materials renders small color differences unimportant. On this account, a tolerance of 5 NBS units is expected to yield a match in general quite satisfactory to the customer.

An exception to this general rule applies to the near-white standards. Near-white colors are very frequently used and the observing conditions are more often such that color tolerances for near-whites are more strict than for other colors. Accordingly, a smaller tolerance is considered necessary to match satisfactorily the near-white standards.

An exception in the opposite sense may be experienced if the color of a plastic be compared to a material of widely different texture or finish, such as a textile. Often a color difference of as much as 10 NBS units or more may be considered an acceptable commercial match in such cases. The most important condition to be satisfied is that the textile duplicate closely the hue of the plastic. 


\section{ACCEPTORS}

The organizations listed below have individually accepted this standard for use as far as practicable in the production, distribution, purchase, or testing of polystyrene plastics. In accepting the standard, they reserved the right to depart therefrom as they individually deem advisable. It is expected that articles which actually comply with the requirements of this standard in all respects will be regularly identified or labeled as conforming thereto, and that purchasers will require such specific evidence of conformity.

\section{ASSOCIATIONS \\ (General Support)}

Limited Price Variety Stores Association, Inc., New York, N. Y.

Plastic Materials Manufacturers Association, Inc., Washington, D. C.

\section{FIRMS AND OTHER INTERESTS}

Admiral Corp., Chicago, $\mathrm{Ill}$.

American Insulator Corp., New Freedom, $\mathrm{Pa}$.

Athol Comb Co., New York, N. Y.

Auburn Button Works, Inc., Auburn, N. Y.

B W Molded Plastics, Pasadena, Calif.

Bakelite Corp., New York, N.Y.

Banner Plastics Corp., New York, N. Y.

Berkeley Engineering \& Manufacturing Co., Berkeley Heights, N. J.

Boonton Molding Co., Boonton, N. J.

Bryant Electric Co., The, Bridgeport, Conn.

Cambridge Molded Plastics Co., Cambridge, Ohio.

Chicago Molded Products Corp., Chicago, Ill.

Colonial Plastics Manufacturing Co., The, Cleveland, Ohio.

DeJur Amsco Corp., Long Island City, N. Y.

Dow Chemical Co., The, Midland, Mich.

Drakenfeld, B. F., \& Co., Inc., New York, N. Y.

Fibro Corp., Garwood, N. J.

General American Transportation Corp., Chicago, IIl.

General Railway Signal Co., Rochester, N. Y.

Guenther, Gaylord S., \& Co., Inc., Niagara Falls, N. Y.

Hoosier Cardinal Corp., Evansville, Ind.

Hoover Co., The, North Canton, Ohio.

Hughes, Tek, Inc., Watervliet, N. Y.

Hungerford Plastics Corp., Murray Hill, N. J.

International Business Machines Corp., Endicott, N. Y.

Kentucky Color \& Chemical Co., Inc., Louisville, Ky.

Keolyn Plastics, Inc., Chicago, Ill.

Kerrville, city of, Kerrville, Tex.

Koppers Co., Inc., Pittsburgh, $\mathrm{Pa}$.

Littelfuse, Inc., Chicago, Ill.

Lone Star Plastics Co., Inc., Fort Worth, Tez.

MacDonald Manufacturing Co., New Baltimore, Mich.

Mack Molding Co., Inc., Wayne, N. J.

Mayco Chemical Co., New York, N. Y.
Meridian Plastics, Inc., Byesville, Ohio.

Meyer, H. Sigmund, St. Louis, Mo.

Michigan Molded Plastics, Inc., Dexter, Mich.

Modern Plastic Co., Los Angeles, Calif.

Modern Plastics Corp., Benton Harbor, Mich.

Monsanto Chemical Co., Springfield, Mass.

Montgomery Ward, Chicago, Ill

Nash-Kelvinator Corp., Detroit, Mich.

National Lock Co., Rockford, Ill.

National Products Co., Kansas City, Mo.

Northern Industrial Chemical Co., South Boston, Mass.

Northwest Plastics, Inc., St. Paul, Minn.

Norton Laboratories, Inc., Lockport, N. Y.

Peerless Plastics, Culver City, Calif.

Plax Corp., Hartford, Conn.

Presstite Engineering Co., St. Louis, Mo.

Pyro Plastics Corp., Union, N. J.

Raymond Laboratories, Inc., St. Paul, Minn.

Robinson Industries, Inc., Franklin Plastics Div1sion, Franklin, $\mathrm{Pa}$.

Sonotone Corp., Elmsford, N. Y.

Southern California Plastic Co., Glendale, Calif.

Southern Plastics Co., Inc., Columbia, S. C.

Sperry Gyroscope Co., Division of the Sperry Corp., Great Neck, N.' Y.

Standard Products Co., The, Plastics Division, St. Clair, Mich.

Sterling Injection Molding, Inc., Buffalo, N. Y.

Sterling Plastics Co., Union, N. J.

Stromberg Carlson Co., Rochester, N. Y.

Teachers College, Columbia Úniversity, New York, N. Y. (General Support.)

Tennessee-Eastman Corp., Kingsport, Tenn.

Unique Creations, Inc., Detroit, Mich.

United Chromium, Inc., New York, N. Y. (General Support.)

United Plastic Industries, Inc., Vassar, Mich.

Victory Plastics Co., Hudson, Mass.

Watertown Manufacturing Co., The, Watertown, Conn.

Wayne Plastic Products, Fort Wayne, Ind.

Westinghouse Electric Corp., Home Radio Division, Sunbury, Pa.

\section{U. S. GOVERNMENT}

Agriculture, U. S. Department of, Division of Purchase, Sales and Traffic, Washington, D. C.

Army, Department of the, Standards Branch, Logistics Division, Washington, D. C. 


\section{ACCEPTANCE OF COMMERCIAL STANDARD}

If acceptance has not previously been filed, this sheet properly filled in, signed, and returned will provide for the recording of your organization as an acceptor of this commercial standard.

\section{Date}

Commodity Standards Division,

National Bureau of Standards,

Washington 25, D. C.

Gentlemen:

We believe that the Commercial Standard CS156-49 constitutes a useful standard of practice, and we individually plan to utilize it as far as practicable in the

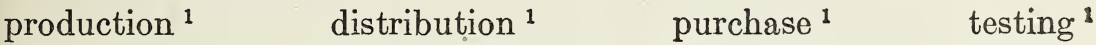

of polystyrene plastics.

We reserve the right to depart from it as we deem advisable.

We understand, of course, that only those articles which actually comply with the standard in all respects can be identified or labeled as conforming thereto.

Signature of authorized officer

(In ink)

(Kindly typewrite or print the following lines)

Name and title of above officer

Organization

(Fill in exactly as it should be listed)

Street address

City, Zone, and State

1 Underscore which one. Please see that separate acceptances are filed for all subsidiary companies and affiliates which should be listed separately as acceptors. In the case of related interests, trade associations, trade papers, etc., desiring to record their general support, the words "General Support" should be added after the signature. 


\section{TO THE ACCEPTOR}

The following statements answer the usual questions arising in connection with the acceptance and its significance:

1. Enforcement.-Commercial standards are commodity specifications voluntarily established by mutual consent of those concerned. They present a common basis of understanding between the producer, distributor, and consumer and should not be confused with any plan of governmental regulation or control. The United States Department of Commerce has no regulatory power in the enforcement of their provisions, but since they represent the will of the interested groups as a whole, their provisions through usage soon become established as trade customs, and are made effective through incorporation into sales contracts by means of labels, invoices, and the like.

2. The acceptor's responsibility.-The purpose of commercial standards is to establish for specific commodities, nationally recognized grades or consumer criteria and the benefits therefrom will be measurable in direct proportion to their general recognition and actual use. Instances will occur when it may be necessary to deviate from the standard and the signing of an acceptance does not preclude such departures; however, such signature indicates an intention to follow the commercial standard where practicable, in the production, distribution, or consumption of the article in question.

3. The Department's responsibility.-The major function performed by the Department of Commerce in the voluntary establishment of commercial standards on a Nation-wide basis is fourfold; first, to act as an unbiased coordinator to bring all interested parties together for the mutually satisfactory adjustment of trade standards; second, to supply such assistance and advice as past experience with similar programs may suggest; third, to canvass and record the extent of acceptance and adherence to the standard on the part of producers, distributors, and users, and fourth, after acceptance, to publish and promulgate the standard for the information and guidance of buyers and sellers of the commodity.

4. Announcement and promulgation.-When the standard has been endorsed by a satisfactory majority of production or consumption in the absence of active, valid opposition, the success of the project is announced. If, however, in the opinion of the Standing Committee or the Department of Commerce, the support of any standard is inadequate, the right is reserved to withhold promulgation and publication. 


\section{COMMERCIAL STANDARDS}

CS No.

0-40. Commercial standards and their value to business (third edition).

1-42. Clinical thermometers (third edition).

2-30. Mopsticks.

3-40. Stoddard solvent (third edition).

4-29. Staple porcelain (all-clay) plumbing fixtures.

5-46. Pipe nipples; brass, copper, steel and wrought-iron (second edition).

$6-31$. Wrought-iron pipe nipples (second edition). Superseded by CS5-46.

7-29. Standard weight malleable iron or steel screwed unions.

8-41. Gage blanks (third edition)

$9-33$. Builders' template hardware (second edition).

10-29. Brass pipe nipples. Superseded by CS5-45.

11-41. Moisture regains of cotton yarns(second edition).

12-48. Fuel oils (sixth edition).

13-44. Dress patterns (fourth edition)

14-43. Boys' button-on waists, shirts, junior and sport shirts (made from woven fabrics) (third edition).

15-46. Men's pajama sizes (made from woven fabrics) (third edition).

16-29. Wall paper.

17-47. Diamond core drill fittings (fourth edition).

18-29. Hickory golf shafts.

19-32. Foundry patterns of wood (second edition).

20-47. Staple vitreous china plumbing fixtures (fourth edition).

21-39. Interchangeable ground-glass joints, stopcocks, and stoppers (fourth edition).

22-40. Builders' hardware (nontemplate) (second edition).

23-30. Feldspar.

24-43. Screw threads and tap-drill sizes.

25-30. Special screw threads. Superseded by CS24-43.

26-30. Aromatic red cedar closet lining.

27-36. Mirrors (second edition).

28-46. Cotton fabric tents, tarpaulins and covers (second edition).

29-31. Staple seats for water-closet bowls.

30-31. Colors for sanitary ware. (Withdrawn as commercial standard, March 15 1949.)

31-38. Wood shingles (fourth edition).

$32-31$. Cotton cloth for rubber and pyroxylin coating.

33-43. Knit underwear (exclusive of rayon) (second edition).

34-31. Bag, case, and strap leather.

35-47. Hardwood plywood (third edition).

36-33. Fourdrinier wire cloth (second edition).

$37-31$. Steel bone plates and screws.

38-32. Hospital rubber sheeting.

39-37. Wool and part wool blankets (second edition). (Withdrawn as commercial standard, July 14, 1941).

40-32. Surgeons' rubber gloves.

41-32. Surgeons' latex gloves.

42-43. Structural fiber insulating board (third edition).

43-32. Grading of sulphonated oils.

44-32. Apple wraps.

45-48. Douglas fir plywood (eighth edition).

46-49. Hosiery lengths and sizes (fourth edition).

47-34. Marking of gold-filled and rolled-goldplate articles other than watchcases.

48-40. Domestic burners for Pennsylvania anthracite (underfeed type) (second edition)

49-34. Chip board, laminated chip board, and miscellaneous boards for book binding purposes.
CS No.

50-34. Binders board for bookbinding and other purposes.

51-35. Marking articles made of silver in combination with gold.

52-35. Mohair pile fabrics (100-percent mohair plain velvet, 100-per cent mohair plain frieze, and 50-percent mohair plain frieze).

53-35. Colors and finishes for cast stone.

54-35. Mattresses for hospitals.

55-35. Mattresses for institutions.

$56-49$. Oak flooring (third edition)

57-40. Book cloths, buckrams, and impregnated fabrics for bookbinding purposes except library bindings (second edition).

58-36. Woven elastic fabrics for use in overalls (overall elastic webbing).

59-44. Textiles-testing and reporting (fourth edition).

60-48. Hardwood dimension lumber (second edition).

61-37. Wood-slat venetian blinds.

62-38. Colors for kitchen accessories.

63-38. Colors for bathroom accessories.

64-37. Walnut veneers.

65-43. Methods of analysis and of reporting fiber composition of textile products (second edition).

66-38. Marking of articles made wholly or in part of platinum.

67-38. Marking articles made of karat gold

68-38. Liquid hypochlorite disinfectant, deodorant, and germicide.

69-38. Pine oil disinfectant.

70-41. Phenolic disinfectant (emulsifying typo) (second edition) (published with CS71-41).

71-41. Phenolic disinfectant (soluble type) (second edition) (published with CS70-41).

72-38. Household insecticide (liquid spray

type).
73-48. Old growth Douglas fir, Sitka spruce, and Western hemlock standard stock doors (fourth edition).

74-39. Solid hardwood wall paneling.

75-42. Automatic mechanical draft oil burners designed for domestic installations (second edition).

76-39. Hardwood inter ior trim and molding.

77-48. Enameled cast-Iron plumbing fixtures (second edition)

78-40. Ground-and-polished lenses for sun glasses (second edition) (published with CS79-40).

79-40. Blown, drawn, and dropped lenses for sun glasses (second edition) (published with CS78-40).

Electric direction signal systems other than semaphore type for commercial and other vehicles subject to special motor vehicle laws (after market).

81-41. Adverse-weather lamps for vehicles (after market).

82-41. Inner-controlled spotlamps for vehicles (after market).

83-41. Clearance, marker, and identification lamps for vehicles (after market).

84-41. Electric tail lamps for vehicles (after market).

85-41. Electric license-plate lamps for vehicles (after market)

86-41. Electric stop lamps for vehicles (after market).

87-41. Red electric warning lanterns.

88-41. Liquid burning flares.

89-40. Haidwood stair treads and risers.

90-49. Power cranes and shovels.

91-41. Factory-fitted Douglas fir entrance doors. 
CS No.

92-41. Cedar, cypress, and redwood tank stock lumber.

93-41. Portable electric drills (exclusive of high frequency).

94-41. Calking lead.

95-41. Lead pipe.

96-41. Lead traps and bends.

97-42. Electric supplementary driving and passing lamps for vehicles (after market).

98-42. Artists' oil paints.

99-42. Gas floor furnaces-gravity circulating type.

100-47. Porcelain-enameled steel utensils (third edition).

101-43. Flue-connected oil-burning space heaters equipped with vaporizing pot-type burners.

102- (Reserved for Diesel and fuel-oil engines.)

103-48. Rayon jacquard velour (with or without other decorative yarn) (second edition).

104-49. Warm-air furnaces equipped with vaporizing-type oil burners (third edition).

105-48. Mineral wool insulation for low temperatures (second edition).

106-44. Boys' pajama sizes (woven fabrics) (second edition).

107-45. Commercial electric-refrigeration condensing units (second edition). (Withdrawn as commercial standard September 4,1947 .)

108-43. Treading automobile and truck tires.

109-44. Solid-fuel-burning forced-air furnaces.

110-43. Tire repairs-vulcanized (passenger, truck, and bus tires).

111-43. Earthenware (vitreous-glazed) plumbing fixtures.

112-43. Homogeneous fiber wallboard.

113-44. Oil-burning floor furnaces equipped with vaporizing pot-type burners.

114-43. Hospital sheeting for mattress protection.

115-44. Porcelain-enameled tanks for domestic use.

116-44. Bituminized-fibre drain and sewer pipe.

117-49. Mineral wool insulation for heated industrial equipment (second edition).

118-44. Marking of jewelry and novelties of

(E)119-45.1 Dial indicators (for linear measurements).

120-48. Standard stock ponderosa pine doors (third edition).

121-45. Women's slip sizes (woven fabrics).

122-45. Western hemlock plywood.

123-49. Grading of diamond powder (second edition).
CS No.

(E) 124-45.1 Master disks

125-47. Prefabricated homes (second edition).

126-45. Tank mounted air compressors.

$127-45$. Self-contained mechanically refrigerated drinking-water coolers.

128-45. Men's sport shirt sizes-woven fabrics (other than those marked with regular neckband sizes).

129-47. Materials for safety wearing apparel (second edition).

130-46. Color materials for art education in schools.

131-46. Industrial mineral-wool products, all types-testing and reporting.

132-46. Hardware cloth.

133-46. Woven wire netting.

134-46. Cast-aluminum cooking utensils (metal composition).

135-46. Men's shirt sizes (exclusive of work shirts).

136-46. Blankets for hospitals (wool, and wool and cotton).

137-46. Size measurements for men's and boys' shorts (woven fabries).

138-47. Insect wire screening.

139-47. Work gloves.

140-47. Testing and rating convectors.

141-47. Sine bars, blocks, plates, and fixtures.

142-47. Automotive lifts.

143-47. Standard strength and extra strength perforated clay pipe.

144-47. Formed metal porcelain enameled sanitary ware.

145-47. Testing and rating hand-fired hot water supply boilers.

146-47. Gowns for hospital patients.

147-47. Colors for molded urea plastics.

148-48. Men's circular flat and rib knit rayon underwear.

149-48. Utility type house dress sizes.

150-48. Hot-rolled rail steel bars (produced from Tee-section rails).

151-48. Body measurements for the sizing of apparel for infants, babies, toddlers and children (for the knit underwear industry).

152-48. Copper naphthenate wood-preservative.

153-48. Body measurements for the sizing of apparel for girls (for the knit underwear industry).

154- . (Reserved for wire rope).

155-49. Body measurements for the sizing of apparel for boys (for the knit underwear industry).

156-49. Colors for polystyrene plastics.

157-49. Ponderosa pine and sugar pine plywood. 158-49. Model forms for girls' apparel.

159-49. Sun glass lenses made of ground and polished plate glass thereafter thermally curved.

Notice.- Those interested in commercial standards with a view toward accepting them as a basis of everyday practice may secure copies of the above standards, while the supply lasts, by addressing the National Bureau of Standards, Washington $25, \mathrm{D}$. C.

I Where "(E)" precedes the CS number, it indicates an emergency commercial standard, drafted under war conditions with a view toward early revision. 